\title{
Tolerance to bolting in lettuce: cultivars and growing seasons
}

\author{
Tolerancia al florecimiento precoz en lechuga: cultivares y épocas de cultivo
}

\author{
Jaqueline Cristina do Amaral ${ }^{1}$, Vanessa Neumann Silva ${ }^{1 *}$
}

\begin{abstract}
Lettuce is the most consumed hardwood crop in the world. Originating in temperate climates, early flowering of lettuce is induced in regions and/or periods of high temperatures. The objective of this work was to evaluate the tolerance to bolting of cultivars of crisp lettuce, during different growing seasons, in the western region of the state of Santa Catarina, Brazil. The experiment was conducted using a randomized complete block design, in a 6 × 2 factorial scheme comprising six cultivars (Milena, Vanda, Vera, Valentina, Pira Verde, and Grand Rapids) and two distinct growing environments (protected and field), during two growing seasons in the summer period. The following were evaluated: days from transplant to flowering, stem length, diameter, total fresh and commercial mass, number of leaves, and commercial and total productivity. Data were submitted to analysis of variance and comparison of means by the Tukey test $(\mathrm{p}<0.05)$. The Pira Verde, Milena, Valentina and Vanda cultivars were found to be tolerant to early tillage under the tested conditions. In the protected environment, the best growing season for crisp lettuce was the first summer period evaluated, involving seedling transplant in February and harvest in April. In contrast, the best growing season in the field environment was the second summer period, with seedling transplant in March and harvest in May.
\end{abstract}

Key words: Lactuca sativa, early flowering, growing environments.

\section{RESUMEN}

La lechuga es la hortalizas de hoja dura más consumida en el mundo. Con origen en regiones de clima templado; en regiones y lo épocas con altas temperaturas ocurre la inducción al florecimiento precoz. El objetivo del trabajo fue evaluar la tolerancia al pimiento precoz de cultivares de lechuga crespa, en diferentes épocas de cultivo, de verano, en la región Oeste del estado de Santa Catarina, producidas en campo y ambiente protegido. El diseño experimental utilizado fue de bloques casualizados, en esquema factorial $6 \times 2$ 2, siendo seis cultivares (Milena, Vanda, Vera, Valentina y Pira Verde Grand Rapids), en dos épocas de cultivo en el período del verano, separadamente para cada ambiente de cultivo (protegido y campo). Se evaluaron: días transcurridos desde el transplante hasta la emisión floral, longitud del cañón, diámetro, masa fresca total y comercial de la planta, número de hojas, productividad comercial y total. Los datos fueron sometidos a análisis de varianza y comparación de promedios por el test de Tukey $(p<0,05)$. Las cultivares Pira Verde, Milena, Valentina y Vanda son tolerantes al pimiento precoz, en las condiciones evaluadas en esta investigación. En el ambiente protegido la mejor época de cultivo de lechuga crespa, en el verano, fue la primera evaluada, con trasplante de mudas en febrero y cosecha en abril. En el ambiente rural la mejor época de cultivo, fue la segunda, con transplante de mudas en el mes de marzo y cosecha en mayo.

Palabras clave: Lactuca sativa, Pimiento, Ambiente de cultivo.

\section{Introduction}

Lettuce is the most consumed hardwood crop in the world. Originating in temperate regions, lettuce develops best under low-temperature and low-light conditions, although thanks to technological and genetic advances it can now be cultivated in a range of climates (Suinaga et al., 2013).
When lettuce plants are subjected to high temperatures, mainly in the summer, they end their vegetative period quickly and emit an early floral stem, which characterizes the commencement of the reproductive stage. This situation is undesirable, since it stimulates the production of the bitter substance latex in the leaves, making the vegetables not only unfit for consumption but also decreasing

\footnotetext{
1 Universidade Federal da Fronteira Sul, campus Chapecó, Santa Catarina, Brazil.

* Corresponding autor: vanessa.neumann@uffs.edu.br
} 
their productivity by reducing the number of leaves per plant (Carvalho Filho et al., 2009).

For producers of this vegetable, early flowering prompts early harvesting to avoid total loss of head quality, which accelerates the vegetative cycle and thereby affects both the price and quantity of product offered in the market (Sala \& Costa, 2012). Thus, for the western region of Santa Catarina in Brazil, as well as many others in which temperatures may exceed $20^{\circ} \mathrm{C}$ even during winter, it is essential to identify cultivars adapted to such conditions.

Considering, according to Cruz (2012), the lack of information regarding lettuce cultivars that are adapted to certain conditions and planting times, the objective of the present research was to evaluate the tolerance to bolting of different cultivars of crisp lettuce grown in different environments (field and protected), during different growing seasons in the summer, in the western region of Santa Catarina (SC), Brazil.

\section{Material and methods}

Experiments were carried out in a rural property within the municipality of Chapecó-SC (latitude $27^{\circ} 08$ ' $52^{\prime}$ ' ' $\mathrm{S}$, longitude $52^{\circ} 63^{\circ} 55^{\circ} \mathrm{W}$ ) at an altitude of 687 meters (INMET), as well as in the greenhouse and post-harvest laboratory of the University. The experimental soil was a Red Dystrophic Latosol (Embrapa, 2004). Soil chemical analysis was performed by collecting samples of the arable layer $(0-20 \mathrm{~cm})$ from the experiment site. The results obtained are shown in Table 1. According to Köppen's classification, the climate of the region is mesothermal, humid subtropical, with hot summers, no defined dry season, and with frequent severe frosts (Cfa). The average annual temperature in Chapecó is less than $20^{\circ} \mathrm{C}$; in winter, temperatures are below zero degrees and in summer do not exceed $38^{\circ} \mathrm{C}$ (EPAGRI, 2016; 2017).

The experimental design took the form of randomized blocks in a $6 \times 2$ factorial scheme 6 cultivars: Milena, Vanda, Vera, Valentina, Pira Verde, and Grand Rapids), and was carried out during two growing seasons in the summer period (February-April and March-May 2017) in two cultivation environments (protected and field), separately. Four replicates were used, with six plots each; each plot consisted of three cultivation lines of ten plants, resulting in 30 plants per plot. The spacing between lines and between plants was 20 $\mathrm{cm} \times 20 \mathrm{~cm}$.

The first stage in the experiment involved the production of seedlings, which was carried out in expanded polystyrene trays of 200 cells, previously washed and disinfected with sodium hypochlorite. Plants were grown in a commercial substrate composed of peat and carbonized rice husk. The seedlings were sprayed with water daily, with 4 to 6 irrigation shifts per day. Twenty days before the transplantation of seedlings and in each growing environment, organic fertilization was carried out incorporating $1.5 \mathrm{~kg} / \mathrm{m}^{2}$ of tanned fertilizer mixed with the bed soil.

Transplantation was performed when the seedlings had 4 true leaves and a well developed root system. Based on the transplant, observations were made regarding the behavior of the cultivars and their respective cultural treatments, such as manual weed control and irrigation. For the evaluation of the studied variables, the eight

Table 1. Values of $\mathrm{pH}$, organic matter $(\mathrm{OM})$, phosphorus $(\mathrm{P})$, potassium $(\mathrm{K})$, potential acidity $\left(\mathrm{H}^{+}+\right.$ $\left.\mathrm{Al}^{3}\right)$, aluminum $\left(\mathrm{Al}^{3}\right)$, calcium $\left(\mathrm{Ca}^{2+}\right)$, total $\mathrm{CTC}\left(\mathrm{CTC}_{\text {total }}\right)$ and base saturation $(\mathrm{BS})$ of soil samples taken from the rural property of the experiment, Chapecó-SC-Brasil.

\begin{tabular}{|c|c|c|c|c|c|c|c|c|c|}
\hline & $\mathrm{pH}$ water & $\mathrm{OM}$ & $\mathrm{P}$ & $\mathrm{K}$ & $\mathrm{H}^{+}+\mathrm{Al}^{3}$ & $\mathrm{Al}^{3+}$ & $\mathrm{Ca}^{2+}$ & $\mathrm{CTC}_{\text {total }}$ & BS \\
\hline Samples & & $(\%)$ & \multicolumn{2}{|c|}{$\left(\mathrm{mg} \mathrm{dm}^{3}\right)$} & \multicolumn{4}{|c|}{$\mathrm{Cmol} \mathrm{dm}^{3}$} & $\%$ \\
\hline Field Sample 1 & 6,3 & 3,5 & 168,9 & 650,0 & 2,48 & 0,00 & 6,9 & 15,97 & 84,50 \\
\hline $\begin{array}{c}\text { Field } \\
\text { Sample } 2\end{array}$ & 6,1 & 3,3 & 168,9 & 650,0 & 2,35 & 0,00 & 7,5 & 16,62 & 85,84 \\
\hline $\begin{array}{l}\text { Greenhouse } \\
\text { Sample } 1\end{array}$ & 6,5 & 3,6 & 74,9 & 400,0 & 2,02 & 0,00 & 6,0 & 11,94 & 83,07 \\
\hline $\begin{array}{c}\text { Greenhouse } \\
\text { Sample } 2\end{array}$ & 5,7 & 2,9 & 60,7 & 400,28 & 3,47 & 0,00 & 5,4 & 12,36 & 71,89 \\
\hline
\end{tabular}


central plants of each plot were used (Lucio et al., 2011). During the first growing season, in both the field and protected environments, all crops were harvested in April 2017 with the exception of those of the Grand Rapids cultivar (cv.), which were harvested on March 31, 2017.

Similarly, during the second cropping season in both environments, all crops were harvested in May 2017 with the exception of Grand Rapids specimens, which were harvested on April 28, 2017. After harvesting in warmer temperatures, all plants were immediately taken to the laboratory for the measurement of the following parameters: number of days from transplanting to flowering, stem length, plant diameter, total fresh mass, commercial fresh mass, number of leaves, and commercial and total productivity, according to Suinaga et al. (2013) and Sousa et al. (2008), as described below. Days between transplantation and flowering: dates corresponding to growth phases were annotated and daily observations were made for each plant. Plant diameter: obtained with the aid of a scale, measuring the ends of the plant. Stem length: obtained using a measuring tape immediately after planting, from the base of the stem (above the roots) until the first insertion of leaves. Total fresh mass: obtained soon after harvesting, with plants taken to the laboratory and weighed in an analytical balance together with all material harvested (roots and leaves). Commercial fresh mass: obtained after the removal of all plant parts that would harm their commercialization and consumption, including roots, withered leaves, rotting material, and blemishes caused by insects and diseases. Number of leaves: determined in all plants in each plot, and including leaves developing at the apex of the plant. Commercial and total productivity of fresh mass: determined considering the total fresh mass and commercial fresh mass in the useful area of the plot (Simões et al., 2015) and estimating for one hectare, with the result expressed in kilograms per hectare and converted to tonnes per hectare. The results were then submitted to analysis of variance and comparison of means via the Tukey test $(p<0.05)$, for each environment separately.

\section{Results and discussion}

According to the obtained results, cv. Grand Rapids plants bolted at 15 and 38 days after transplantation (DAT) in the protected environment during the first and second growing seasons, respectively. In contrast, of the remaining cultivars, only cv. Vera, at 46 DAT during the first growing season, emitted a floral stem in either period (Table 2).

This outcome is highly significant, because although cv. Grand Rapids is indicated for summer production in the south of Brazil, the occurrence of bolting at 15 DAT provided insufficient time for adequate crop development, considering that a period of at least at least 50 days in the summer is required, at least according to seed-marketing companies (Horticeres, 2016; Isla, 2016).

Indeed, the Grand Rapids cultivar is characterized as being susceptible to bolting; According to Carvalho et al. (2009), studying F4 families of crispleaf lettuce with tolerance to early bolting, when compared to cultivar Grand Rapids, 21 families were more tolerant to early bolting. The main factor influencing the development of lettuce plants is air temperature, with plant performance reduced by the induction of bolting at temperatures above $20^{\circ} \mathrm{C}$ (Santos et al., 2009). In spite of their numerous advantages, many greenhouses behave poorly from a thermal point of view, being characterized by high temperatures during the day despite natural ventilation, and nightly temperatures often lower than the tolerance of the cultivated plants (Silva et al., 2003).

In the present study, average temperatures were 22.8 and $20.8{ }^{\circ} \mathrm{C}$ during the first (February to April) and second (March to May) growing seasons (Figure 1), respectively. This difference of $2{ }^{\circ} \mathrm{C}$ was thus likely sufficient to influence plant development.

According to Brunini et al. (1976), when lettuce plants are exposed to temperatures higher than 22 ${ }^{\circ} \mathrm{C}$, their rate of development decreases. The ideal temperature range for lettuce plant growth is 15.5 to $18.3^{\circ} \mathrm{C}$, although plants can tolerate temperatures of between 26.6 and $29.4{ }^{\circ} \mathrm{C}$ for a few days, provided that nightly temperatures are lower (Sanders, 2017). Prolonged exposure to temperatures in the range of 21.1 to $26.6^{\circ} \mathrm{C}$ can promote stem elongation (bolting) and impair the formation of commercial heads (Resende et al., 2017).

In terms of stem length (CC), plants of the Milena and Pira Verde cultivars exhibited significantly lower growth than those of cv. Grand Rapids during the first growing season; no other differences between cultivars were observed. 
Table 2. Mean values of days between transplantation to bolting (DTB), stem length (SL), plant diameter (PD), total fresh mass (TFM) and commercial mass (CM), number of leaves (NL), total productivity and commercial (CP) of lettuce, of different cultivars, grown in greenhouse, in two growing seasons, in Chapecó-SC, Brazil.

\begin{tabular}{|c|c|c|c|c|c|c|}
\hline \multirow{3}{*}{ Growth season } & \multicolumn{6}{|c|}{ Cultivar } \\
\hline & Grand Rapids & Milena & Pira Verde & Valentina & Vanda & Vera \\
\hline & \multicolumn{6}{|c|}{ DTB } \\
\hline Feb-Apr & 15 & WB** & WB & WB & WB & 46 \\
\hline \multirow[t]{2}{*}{ Mar-May } & 38 & WB & WB & WB & WB & WB \\
\hline & \multicolumn{6}{|c|}{$\mathrm{SL}(\mathrm{cm})$} \\
\hline Feb-Apr & $13,03 \mathrm{aA}^{*}$ & $4,47 \mathrm{bC}$ & $7,69 \mathrm{aB}$ & $7,15 \mathrm{aB}$ & $9,21 \mathrm{aB}$ & $9,06 \mathrm{aB}$ \\
\hline Mar-May & $13,70 \mathrm{aA}$ & $9,84 \mathrm{aB}$ & $6,51 \mathrm{aC}$ & $7,15 \mathrm{aC}$ & $5,96 \mathrm{bC}$ & $9,35 \mathrm{aB}$ \\
\hline \multirow[t]{2}{*}{ CV (\%) } & \multicolumn{6}{|c|}{11,49} \\
\hline & \multicolumn{6}{|c|}{$\mathrm{PD}(\mathrm{cm})$} \\
\hline Feb-Apr & $41,56 \mathrm{aA}$ & $44,17 \mathrm{aA}$ & $40,92 \mathrm{bA}$ & $41,21 \mathrm{aA}$ & $41,10 \mathrm{bA}$ & $44,92 \mathrm{aA}$ \\
\hline Mar-May & $38,39 \mathrm{aB}$ & $46,17 \mathrm{aA}$ & $44,92 \mathrm{aA}$ & $38,78 \mathrm{aB}$ & $49,13 \mathrm{aA}$ & $44,81 \mathrm{aA}$ \\
\hline \multirow[t]{2}{*}{$\mathrm{CV}(\%)$} & \multicolumn{6}{|c|}{5,50} \\
\hline & \multicolumn{6}{|c|}{ NL } \\
\hline Feb-Apr & $13,74 \mathrm{aD}$ & $17,06 \mathrm{bCD}$ & $27,74 \mathrm{aA}$ & $24,53 \mathrm{aAB}$ & $25,62 \mathrm{aAB}$ & $20,38 \mathrm{aBC}$ \\
\hline Mar-May & $14,10 \mathrm{aB}$ & $20,92 \mathrm{aA}$ & $19,40 \mathrm{bAB}$ & $18,88 \mathrm{bAB}$ & $21,10 \mathrm{bA}$ & $15,85 \mathrm{bAB}$ \\
\hline \multirow[t]{2}{*}{$\mathrm{CV}(\%)$} & \multicolumn{6}{|c|}{12,92} \\
\hline & \multicolumn{6}{|c|}{ TFM (g) } \\
\hline Feb-Apr & $232,22 \mathrm{aC}$ & $332,66 \mathrm{bBC}$ & $569,68 \mathrm{aA}$ & $431,85 \mathrm{aB}$ & $411,47 \mathrm{aB}$ & $441,87 \mathrm{aB}$ \\
\hline Mar-May & $308,35 \mathrm{aBC}$ & $468,42 \mathrm{aA}$ & $373,9 \mathrm{bAB}$ & $402,02 \mathrm{aAB}$ & $461,49 \mathrm{aA}$ & $209,37 \mathrm{bC}$ \\
\hline \multirow[t]{2}{*}{$\mathrm{CV}(\%)$} & \multicolumn{6}{|c|}{15,07} \\
\hline & \multicolumn{6}{|c|}{$\mathrm{CM}(\mathrm{g})$} \\
\hline Feb-Apr & $161,58 \mathrm{bC}$ & $261,53 \mathrm{bBC}$ & $489,66 \mathrm{aA}$ & $348,33 \mathrm{aB}$ & $330,92 \mathrm{aB}$ & $336,78 \mathrm{aB}$ \\
\hline Mar-May & $253,13 \mathrm{aC}$ & $344,50 \mathrm{aAB}$ & $312,75 \mathrm{bAB}$ & $305,99 \mathrm{aAB}$ & $394,91 \mathrm{aA}$ & $164,50 \mathrm{bC}$ \\
\hline \multirow[t]{2}{*}{$\mathrm{CV}(\%)$} & \multicolumn{6}{|c|}{15,72} \\
\hline & \multicolumn{6}{|c|}{$\mathrm{TP}\left(\mathrm{t} \mathrm{ha}^{-1)}\right.$} \\
\hline Feb-Apr & $8,29 \mathrm{aC}$ & $11,88 \mathrm{bBC}$ & $20,34 \mathrm{aA}$ & $15,42 \mathrm{aB}$ & $14,69 \mathrm{aB}$ & $15,78 \mathrm{aB}$ \\
\hline Mar-May & $11,01 \mathrm{aBC}$ & $16,72 \mathrm{aA}$ & $13,35 \mathrm{bAB}$ & $14,35 \mathrm{aAB}$ & $16,48 \mathrm{aA}$ & $7,47 \mathrm{bC}$ \\
\hline \multirow[t]{2}{*}{$\mathrm{CV}(\%)$} & \multicolumn{6}{|c|}{15,07} \\
\hline & \multicolumn{6}{|c|}{$\mathrm{CP}\left(\mathrm{tha}^{-1}\right)$} \\
\hline Feb-Apr & $5,77 \mathrm{bC}$ & $9,34 \mathrm{bBC}$ & $17,48 \mathrm{aA}$ & $12,44 \mathrm{aB}$ & $11,81 \mathrm{aB}$ & $12,02 \mathrm{aB}$ \\
\hline Mar-May & $9,04 \mathrm{aBC}$ & $12,30 \mathrm{aAB}$ & $11,16 \mathrm{bAB}$ & $10,92 \mathrm{aAB}$ & $14,10 \mathrm{aA}$ & $5,87 \mathrm{bC}$ \\
\hline
\end{tabular}

*Means followed by the same lowercase letter in the column and upper case in the row do not differ by Tukey's test $(\mathrm{p}<0.05)$. ${ }^{* *} \mathrm{WB}$ : without bolting.

Grand Rapids plants also presented the greatest stem length of all the studied cultivars, which likely explains their similar precocity in the emission of the floral tassel.

Not only is the stem length parameter directly associated with tolerance to bolting, it is also commercially undesirable as it affects head and leaf formation, as well as interfering with leaf quality (Da Luz et al., 2009). In the present study a strong negative correlation between stem length and other parameters was observed, a pattern that confirms the hypothesized susceptibility of cv. Grand Rapids plants. In both planting seasons, specimens of this cultivar exhibited a long stem at $13 \mathrm{~cm}$, and as a consequence presented a smaller number of leaves, smaller diameter, lower total and commercial fresh mass, and consequently lower productivity in relation to that of the other cultivars (Table 2). 
40,0
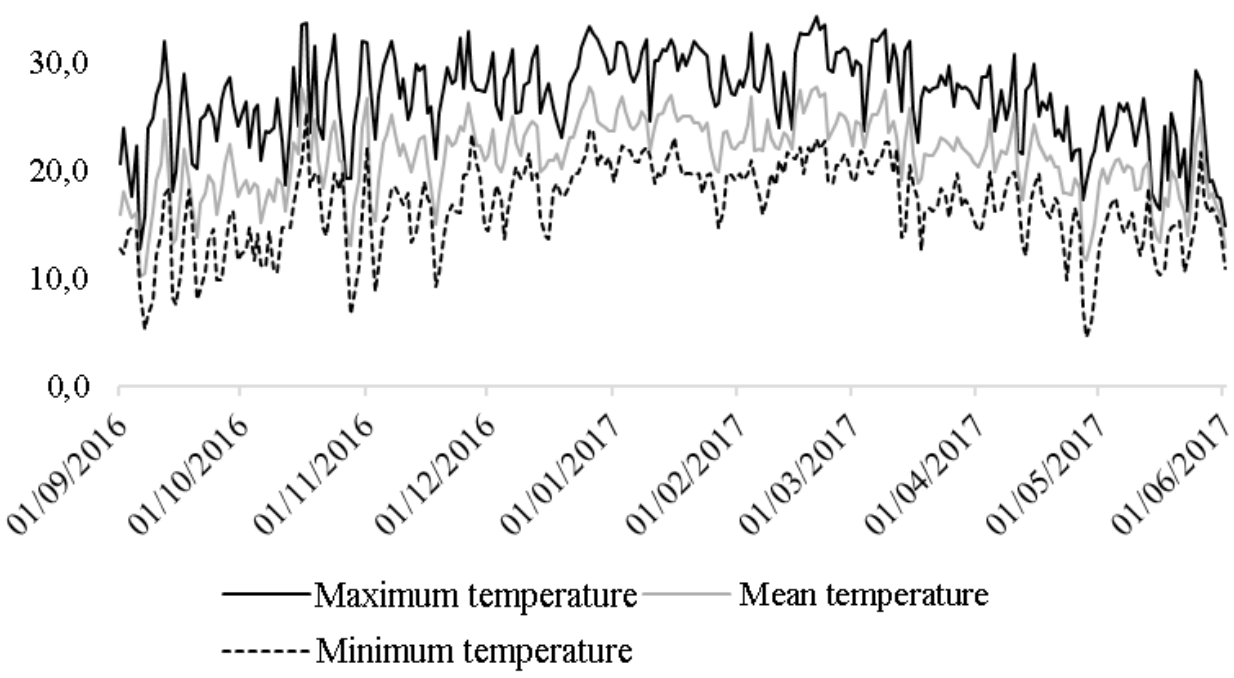

B

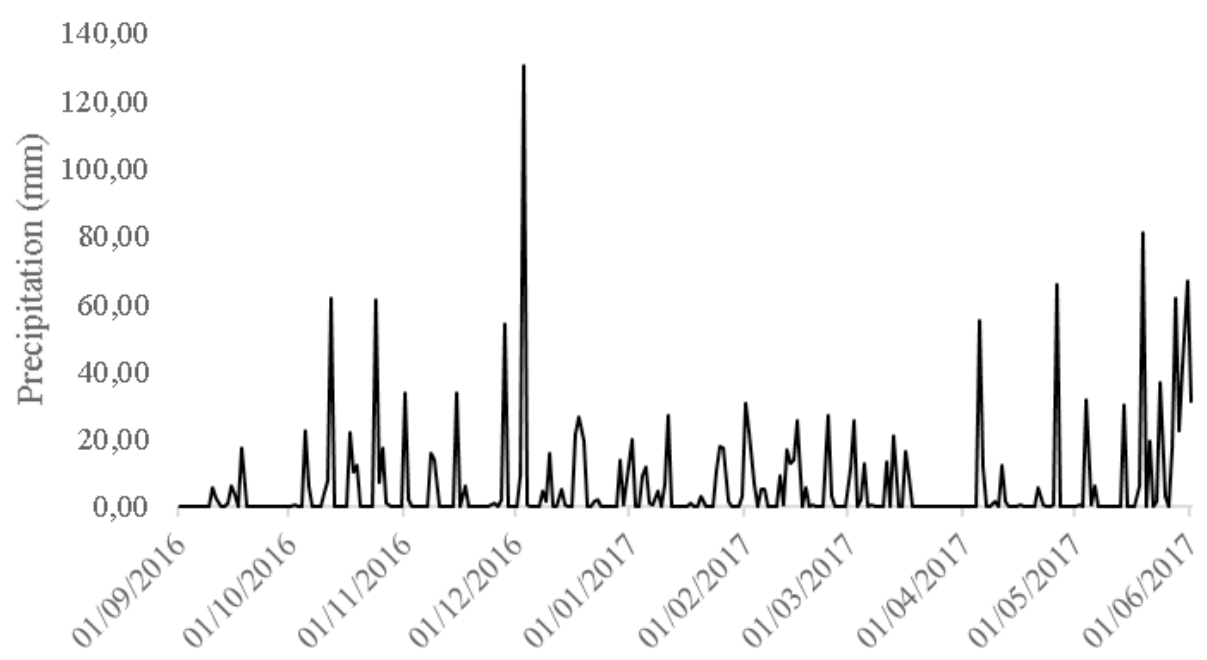

Figure 1. Mean (A) minimum, maximum and average temperatures and accumulated total precipitation (B), in Chapecó-SC, during the experimental period. Source: Epagri / Ciram.

Regarding plant diameter (DP), only the Grand Rapids and Valentina cultivars exhibited a lower performance in the second growing season, with no differences recorded between the remaining cultivars in the first and second seasons. Although the cultivars studied in this research are classified as crisp, with no compact head formation, plant diameter is nevertheless an important visual characteristic for the commercialization and consumption of these vegetables (Henz, 2009).

In terms of leaf number (NF), no difference was observed between the two growing seasons for cv. Grand Rapids plants, which also presented smaller leaves than the other tested cultivars during both periods (Table 2). In contrast, the NF values of the other cultivars varied between seasons, 
with better performance recorded in the first. This characteristic is of great importance for lettuce cultivation, since it both affects the commercial value of the vegetable and provides an indication of the plant's genetic adaptation to the cultivation environment (Diamante et al., 2013).
Cultivar total fresh mass (MFT) and commercial mass (MFC) differed with growing season. Whereas cv. Pira Verde plants exhibited the highest MFT values during the first season (Table 3 ), in the second season the Milena and Vanda cultivars presented better growth than Grand Rapids and

Table 3. Mean values of days between transplantation to bolting (DTB), stem length (SL), plant diameter (PD), total fresh mass (TFM) and commercial mass (CFM), number of leaves (NL), total productivity and commercial (CP) of lettuce, of different cultivars, grown in field, in two growing seasons, in Chapecó-SC, Brazil.

\begin{tabular}{|c|c|c|c|c|c|c|}
\hline \multirow{3}{*}{ Growth season } & \multicolumn{6}{|c|}{ Cultivar } \\
\hline & Grand Rapids & Milena & Pira Verde & Valentina & Vanda & Vera \\
\hline & \multicolumn{6}{|c|}{ DTB } \\
\hline Feb-Apr & 21 & $\mathrm{WB} * *$ & WB & WB & WB & WB \\
\hline \multirow[t]{2}{*}{ Mar-May } & 45 & WB & WB & WB & WB & WB \\
\hline & \multicolumn{6}{|c|}{$\mathrm{SL}(\mathrm{cm})$} \\
\hline Feb-Apr & $9,69 \mathrm{aA}^{*}$ & $5,13 \mathrm{aD}$ & $8,7 \mathrm{aAB}$ & $7,89 \mathrm{aBC}$ & $7,78 \mathrm{aBC}$ & $6,86 \mathrm{aC}$ \\
\hline Mar-May & $6,07 \mathrm{bA}$ & $4,89 \mathrm{aAB}$ & $3,38 \mathrm{bC}$ & $4,07 \mathrm{bBC}$ & $5,1 \mathrm{bAB}$ & $4,21 \mathrm{bBC}$ \\
\hline \multirow[t]{2}{*}{ CV $(\%)$} & \multicolumn{6}{|c|}{10,12} \\
\hline & \multicolumn{6}{|c|}{$\mathrm{PD}(\mathrm{cm})$} \\
\hline Feb-Apr & $30,38 \mathrm{aBC}$ & $27,92 \mathrm{aC}$ & $35,96 \mathrm{aA}$ & $33,32 \mathrm{aAB}$ & $32,42 \mathrm{bABC}$ & $32,92 \mathrm{aAB}$ \\
\hline Mar-May & $32,88 \mathrm{aAB}$ & $29,92 \mathrm{aB}$ & $29,78 \mathrm{bB}$ & $34,92 \mathrm{aA}$ & 36,17 aA & $31,67 \mathrm{aAB}$ \\
\hline \multirow[t]{2}{*}{$\mathrm{CV}(\%)$} & \multicolumn{6}{|c|}{6,56} \\
\hline & \multicolumn{6}{|c|}{ NL } \\
\hline Feb-Apr & $11,24 \mathrm{bC}$ & $11,67 \mathrm{bC}$ & $21,17 \mathrm{aB}$ & $24,74 \mathrm{aAB}$ & $27,84 \mathrm{aA}$ & $23,46 \mathrm{aAB}$ \\
\hline Mar-May & $27,53 \mathrm{aA}$ & $18,67 \mathrm{aC}$ & $20,85 \mathrm{aBC}$ & $22,24 \mathrm{aABC}$ & $25,56 \mathrm{aAB}$ & $21,20 \mathrm{aABC}$ \\
\hline \multirow[t]{2}{*}{$\mathrm{CV}(\%)$} & \multicolumn{6}{|c|}{14,01} \\
\hline & \multicolumn{6}{|c|}{ TFM (g) } \\
\hline Feb-Apr & $220,26 \mathrm{bBC}$ & $167,01 \mathrm{bC}$ & 442,95 aA & 497,12 aA & $388,50 \mathrm{bAB}$ & $390,76 \mathrm{bAB}$ \\
\hline Mar-May & $519,35 \mathrm{aB}$ & $449,17 \mathrm{aB}$ & $439,73 \mathrm{aB}$ & $500,82 \mathrm{aB}$ & $797,22 \mathrm{aA}$ & $619,70 \mathrm{aAB}$ \\
\hline \multirow[t]{2}{*}{$\mathrm{CV}(\%)$} & \multicolumn{6}{|c|}{20,75} \\
\hline & \multicolumn{6}{|c|}{ CFM (g) } \\
\hline Feb-Apr & $129,68 \mathrm{bB}$ & $99,92 \mathrm{bB}$ & $375,05 \mathrm{aA}$ & $367,46 \mathrm{aA}$ & $332,10 \mathrm{bA}$ & $322,97 \mathrm{bA}$ \\
\hline Mar-May & $347,36 \mathrm{aB}$ & $298,09 \mathrm{aB}$ & $319,41 \mathrm{aB}$ & $354,0 \mathrm{aB}$ & $645,02 \mathrm{aA}$ & $454,40 \mathrm{aB}$ \\
\hline \multirow[t]{2}{*}{$\mathrm{CV}(\%)$} & \multicolumn{6}{|c|}{26,03} \\
\hline & \multicolumn{6}{|c|}{$\mathrm{TP}\left(\mathrm{t} \mathrm{ha}^{-1}\right)$} \\
\hline Feb-Apr & $7,86 \mathrm{bBC}$ & $5,96 \mathrm{bC}$ & $15,88 \mathrm{aA}$ & $17,75 \mathrm{aA}$ & $13,87 \mathrm{bAB}$ & $13,94 \mathrm{bAB}$ \\
\hline Mar-May & $18,54 \mathrm{aB}$ & $16,04 \mathrm{aB}$ & $15,70 \mathrm{aB}$ & $17,52 \mathrm{aB}$ & $28,47 \mathrm{aA}$ & $22,13 \mathrm{aAB}$ \\
\hline \multirow[t]{2}{*}{ CV (\%) } & \multicolumn{6}{|c|}{20,99} \\
\hline & \multicolumn{6}{|c|}{$\mathrm{CP}\left(\mathrm{t} \mathrm{ha}^{-1}\right)$} \\
\hline Feb-Apr & $4,63 \mathrm{bB}$ & $3,56 \mathrm{bB}$ & $13,32 \mathrm{aA}$ & $13,12 \mathrm{aA}$ & $11,86 \mathrm{bA}$ & $11,53 \mathrm{bA}$ \\
\hline Mar-May & $12,40 \mathrm{aB}$ & $10,64 \mathrm{aB}$ & $11,40 \mathrm{aB}$ & $12,64 \mathrm{aB}$ & $23,03 \mathrm{aA}$ & $16,22 \mathrm{aB}$ \\
\hline CV (\%) & & & & & & \\
\hline
\end{tabular}

*Means followed by the same lowercase letter in the column and upper case in the row do not differ by Tukey's test $(\mathrm{p}<0.05)$.*WB: without bolting. 
Vera plants. Cultivar MFC values exhibited generally the same pattern as that observed for MFT during the two evaluated periods, with the exception that cv. Grand Rapids showed the best performance in the second growing season.

The fresh mass (total and commercial) values of some cultivars grown in the protected environment are higher than those obtained by Queiroz et al. (2014) in Cáceres-MT, which achieved a mean of 301.14 (g plant $^{-1}$ ). Although this value is slightly closer to that obtained here, the variation between the two studies reflects the differences in adaptation and performance of lettuce cultivars grown in protected environments in different regions of Brazil (SC and MT).

Total and commercial productivity (PT and PC) differed between cultivars and growing seasons. The Pira Verde cultivar again stood out in the first season, achieving values of $20.34 \mathrm{tha}^{-1}$ and 17.48 $\mathrm{t} \mathrm{ha}^{-1}$, respectively. All the other studied cultivars exhibited higher total and commercial yields in the second growing season, with the exception of $\mathrm{cv}$. Vera. Lettuce crop productivity is the result of several factors, including planting density, plant arrangement in space, choice of cultivar with genetic potential, as well as production in an environment protected against adverse agrometeorological conditions, such as reductions in air and soil temperatures, and inadequate relative air humidity (Santos et al., 2009).

In the experiment conducted in the field, only Grand Rapids cultivar plants exhibited bolting, which took place during the first and second growing seasons at 21 and 45 DAT (Table 3), respectively. The average temperature during the second season was slightly lower than that during the first, at 22.8 ${ }^{\circ} \mathrm{C}$ and $24.4{ }^{\circ} \mathrm{C}$, respectively (Figure 1).

In terms of stem length (CC), higher values were observed in the first season for all cultivars with the exception of cv. Milena. Furthermore, cv. Grand Rapids plants presented the greatest stem length during both seasons. According to Santos (2009), normal stems in lettuce are $\leq 6 \mathrm{~cm}$ length; although those $\leq 9 \mathrm{~cm}$ are considered acceptable, larger stems may present evidence of susceptibility to herbivory. Plants with shorter stems are thus able to stay longer in the field to form leaves (Santos et al., 2009).

Whereas plant diameter (DP) was greater in the Pira Verde cultivar than in the Grand Rapids, Milena and Vanda cultivars during the first growing season, during the second season the Valentina and Vanda cultivars performed better than Milena and Pira Verde plants. In terms of variation with season, significant differences were recorded only for the Vanda and Pira Verde cultivars. The DP data obtained here are similar to those recorded by Santi et al. (2013), who examined both other crisp cultivars and those of the curly group, with values varying at around 29.5 to $31.9 \mathrm{~cm}$.

The number of leaves (NF) observed was significantly lower in the first season for Grand Rapids and Milena plants, with no significant difference between growing seasons recorded for any other cultivar. Whereas cv. Vanda presented a significantly higher number of leaves compared to the Pira Verde, Milena and Grand Rapids cultivars during the first growing season, during the second season, cv. Grand Rapids was superior to the Milena and Pira Verde cultivars in this characteristic.

The NF values obtained here are similar to those reported in other studies. For example, Resende et al. (2016) examined cv. Vanda plants under summer growing conditions in the Brazilian Cerrado region, achieving an average number of leaves per plant of 30.65. Elsewhere, the Valentina, Milena and Vera cultivars were grown in summer in Jataí-GO, Brazil, with respective NF values of 37, 29.9 and 20.2 recorded under minimum, average and maximum temperatures of 19.6, 26.1 and $34.9{ }^{\circ} \mathrm{C}$, respectively.

Thus, the NF values obtained in the present work differ from those of Sousa et al. (2018), especially regarding the Milena and Valentina cultivars, which presented a smaller number of leaves. This discrepancy demonstrates the importance of such research, since although all the cultivars under study are indicated for the regions mentioned, their performance varied considerably due to local climatic conditions.

In fact, according to Santos et al. (2009), the use of plant cultivars that are characterized by a larger diameter, and consequently more leaves and a greater fresh mass, becomes a competitive advantage for the producer. In their analysis of the performance of crisp lettuce cultivars under high temperature conditions, the latter authors recorded 9.7 and 20.4 leaves per plant, reflecting the genetic influence on plant growth. These values are similar to those obtained in the present study, in which an average number of leaves of around 11 was recorded for the Grand Rapids and Milena cultivars, and 27 for $\mathrm{cv}$. Vanda during 
the first growing season. Differences were also observed in relation to season for some cultivars, reflecting the fact that environmental factors are also partly responsible for the physiological and morphological transformations of herbaceous plants, including diameter and leaf number (Hermes et al., 2001).

In terms of total fresh mass (MFT), the Pira Verde and Valentina cultivars did not differ significantly between growing seasons, although higher performance was recorded during the first season. In contrast, all the other cultivars under study presented a greater mass during the second growing season, especially cv. Vanda; the latter plants presented significantly higher MFT values than the majority of cultivars, with the exception of cv. Vera during the second season.

Pira Verde and Valentina plants also did not vary significantly in commercial fresh mass (MFC) between seasons, with the Pira Verde, Valentina, Vanda and Vera cultivars recording the largest values during the first season, and cv. Vanda in the second.

Lettuce plant total and commercial productivity (PT and PC) behavior was the same as that observed for MFT and MFC, with only the Pira Verde and Valentina cultivars exhibiting no influence of season on productivity; all other cultivars presented higher productivity during the second growing season. The highest PT values during the first season were recorded for cv. Pira Verde and cv. Valentina, at $15.88 \mathrm{t} \mathrm{ha}^{-1}$ and $17.75 \mathrm{t} \mathrm{ha}^{-1}$, respectively. It is worth noting that these values are much higher than those of the other cultivars, reflecting the high productive potential of these two cultivars under the stress of summer cropping. During the second growing season, only cv. Vanda at $28.47 \mathrm{t} \mathrm{ha}^{-1}$ exhibited significantly higher PT. In terms of PC, the Pira Verde, Valentina, Vanda and Vera cultivars presented higher values in the first growing season, while in the second only $\mathrm{cv}$. Vanda was again significantly more productive, at 23.03 $\mathrm{t} \mathrm{ha}^{-1}$.

Considering all the results presented above, the evaluation of lettuce cultivars classified as 'tropicalized' is essential, as not all will perform well in different locations, growing seasons and (micro-)climates, particularly in the face of ongoing climate change. In addition, although crisp lettuce is in high demand in Brazil, according to Sala (2011) its genetic improvement is not a priority in temperate regions or even for seed companies, since the 'Grand Rapids' lettuce segment is not typically found in domestic markets in these countries. Rather, international research and development has been directed toward American, Roman, mini and baby leaf varieties.

Thus, research is required that examines the climatic conditions and cultivation times of cultivars of crisp lettuce in order to increase the efficiency of the Brazilian cultivation system. In the present study, the performance of the selected crisp lettuce cultivars was directly influenced by the cultivation environment and planting season in western Catarinense. Cultivars varied in their tolerance to bolting, with characteristics of commercial importance, such as plant diameter, number of leaves, fresh mass and productivity, better in the second, cooler, growing season.

\section{Conclusions}

The cultivars Pira Verde, Milena, Valentina and Vanda are tolerant to bolting under the conditions evaluated in this research. In the protected environment, the best summer growing season was the first evaluated, involving transplantation of seedlings in February and harvest in April. In the field environment the best growing season was the second, with seedling transplant in March and harvest in May.

\section{Literature Cited}

Brunini, O.; Lísbão, R.S.; Bernardi, J.B.; Fornasier, J.B. 1976. Temperatura base para alface cultivar White Boston, em um sistema de umidade térmico. Bragantia, 35 (1): 213-219.

Carvalho Filho, J.L.S.; Gomes, L.A.A.; Maluf, W.R.

2009. Tolerância ao florescimento precoce e características comerciais de progênies F4 de alface do cruzamento Regina 71 x Salinas 88. Acta Scientiarum Agronomy, 31 (1): 37-42.
Cruz, T.P.

2012. Desempenho agronômico de cultivares de alface para as condições edafoclimáticas da região de Alegre-ES. Nucleus, 9(1): 43-50.

Da Luz, A.O.; Seabra Jr, S.; Souza, S.B.S.; Nascimento, A.L. 2009. Resistência ao pendoamento de genótipos de alface em ambientes de cultivo. Agrarian, 2 (6): 71-82. 
Diamante, M.S.; Seabra Jr, S.; Inagaki, A.M.; Silva, M.B.; Dallacort, $\mathrm{R}$

2013. Produção e resistência ao pendoamento de alfaces tipo lisa cultivadas sob diferentes ambientes. Revista Ciência Agronômica, 44 (1): 133-140.

EMBRAPA.

2004. Solos do Estado de Santa Catarina. Embrapa Solos. Rio de Janeiro, Brazil. 694p.

\section{EPAGRI-CIRAM}

Monitoramento climatológico no estado de Santa Catarina, Brasil: http://ciram.epagri.sc.gov.br. Consulted: 01/ sep/ 2016.

Henz, G.P.; Suinaga, F.A.

2009. Tipos de alface cultivados no Brasil. HortaliçasComunicado Técnico n.75. Embrapa. Brazil. 7p.

Hermes, C.C.; Medeiros, S.L.P.; Manfron, P.A.; Caron, B.; Pommer, S.F.; Bianchi, C.

2001. Emissão de folhas de alface em função de soma térmica. Revista Brasileira de Agrometeorologia, 9 (2): 269-275.

Horticeres.

2016. Catálogo de produtos. Horticeres Sementes. Available: http://www.horticeres.com.br/downloads/catalogos. Consulted: 03 /sept/ 2016.

Isla.

2016. Catálogo de produtos. Isla Sementes. Available: https:// isla. com.br/arquivos-para-download/catalogos. Consulted: 02/sep/2016.

Queiroz, J.P.S.; Costa, A.J.M.; Neves, L.G.; Seabra Jr, S.; Barelli, M.A.A.

2014. Estabilidade fenotípica de alfaces em diferentes épocas e ambientes de cultivo. Revista Ciência Agronômica, 45 (2), 276-283.

Resende, F.V.; Domingues Neto, F.J.; Gualberto, R.; Vidal, M.C.; Suinaga, F.A.

2016. Cultivares de alface para a agricultura orgânica no período de Verão do Cerrado. Hortaliças-Boletim de Pesquisa e Desenvolvimento, n.138. Embrepa. Brazil. 19p.

Resende, G.M.; Costa, N.D.; Yuri, J.E.; Mota, J.H.

2017.Adaptação de genótipos de alface crespa em condições semiáridas. Revista Brasileira de Agricultura Irrigada, 11 (1): 1145 - 1154.
Sala, F.C.

2011. Melhoramento genético de alface. Horticultura Brasileira, 29 (2), (Suplemento - CD ROM).

Sala, F.C, Costa, C.P.

2012. Retrospectiva e tendência da alfacicultura brasileira. Horticultura Brasileira, 30 (2): 187-194.

Sanders, D.C.

Lettuce production. NC State Extension Publications. Available: https://content.ces.ncsu.edu/lettuce. Consulted: 30/ oct/2017.

Santi A.; Scaramuzza, W.L.M.P.; Neuhaus, A.; Dallacort, R.; Krause, W.; Tieppo, R.C.

2013. Desempenho agronômico de alface americana fertilizada com torta de filtro em ambiente protegido. Horticultura Brasileira, 31(2): 338-343.

Santos, C.L.; Seabra JR, S; Lalla, J.G.; Theodoro, V.C.A; Nespoli, A. 2009. Desempenho de cultivares de alface tipo crespa sob altas temperaturas em Cáceres-MT. Agrarian, 2 (3): 87-98.

Silva, E.C.; Leal, N.R.; Maluf, W.R.

1999. Avaliação de cultivares de alface sob altas temperaturas em cultivo protegido em três épocas de plantio na região norte-fluminense. Ciência Agrotecnologia, 23(3): 491-499.

Silva, E.T.; Byllardt, L.V.B.; Gomes, S.; Wolf, G.D.

2003. Comportamento da temperatura do ar sob condições de cultivo em ambiente protegido. Revista Acadêmica: Ciências Agrárias e Ambientais, 1 (1): 51-54.

Simões, A.C.; Alves, G.K.E.B.; Ferreira, R.L.F.; Araujo Neto, S.E. 2015. Qualidade da muda e produtividade de alface orgânica com condicionadores de substrato. Horticultura Brasileira, 33 (4): 521-526.

Sousa, M.C.M.; Resende, L.V.; Menezes, D.; Loges, v.; Souto, T.A.; Santos, V.F.

2008. Variabilidade genética para características agronômicas em progênies de alface tolerantes ao calor. Horticultura Brasileira, 26 (3): 354-358.

Sousa, V.S.; Mota, J.H.; Carneiro, L.F.; Yuri, J.E.; Resende, G.M. 2018. Desempenho de alfaces do grupo solta crespa cultivadas no verão em Jataí-GO. Cultura Agronômica, 27 (3): 288-296.

Suinaga, F.A.; Boiteux, L.S.; Cabral, C.S.; Rodrigues, C.S. 2013. Métodos de avaliação do florescimento precoce e identificação de fontes de tolerância ao calor em cultivares de alface do grupo varietal 'crespa'. Comunicado técnico Embrapa Hortaliças. Brazil. 4p. 